\title{
EVALUATION OF PROBIOTICS, PREBIOTICS AND SYNBIOTICS AS ALTERNATIVES TO ANTIBIOTIC GROWTH PROMOTERS ON GROWING JAPANESE QUAIL
}

\author{
I. A. Abdel-Kader, A. A. Abdel-Wahab, E.A.M. Ahmad and Enas A. El-Full \\ ${ }^{1}$ Poultry Production Department, Faculty of Agriculture, Fayoum University, 63514 Fayoum, Egypt. \\ *Email: iaa03@fayoum.edu.eg \\ ${ }^{2}$ Animal and Poultry Production Department, Faculty of Agriculture and Natural Resources, Aswan \\ University, 81528 Aswan, Egypt.
}

(Received 1/11/2017, accepted 17/12/2017)

\section{SUMMARY}

\begin{abstract}
$\mathrm{A}$ total of 225 one day-old quail were randomly distributed at equal body weights into five groups at 10 days of age as control group (with no additives), antibiotic group (control diet + sub-therapeutic dose of avilamycin $8 \mathrm{mg} / \mathrm{kg}$ diet ), prebiotic group (control diet $+800 \mathrm{~g}$ Biolex ${ }^{\circledR}$ MB40/ton), probiotic group (control diet $+400 \mathrm{~g}$ AmPhi-BACT/ton) synbiotic group (control diet $+800 \mathrm{~g}$ Pre $+400 \mathrm{~g}$ Pro). Each group was replicated three times, 15 chicks/ replicate. The best alternative to antibiotic in terms of overall growth measures was the synbiotic which had the heaviest live body weight $38 \mathrm{~d}$, body weight gain , faster growth rate , lower feed conversion and had the best performance index during the period 10 to 38 than other treatments $(234.42 \mathrm{~g}, 192.98 \mathrm{~g}, 1.4 \mathrm{~g} / \mathrm{g}, 2.81 \mathrm{~g} / \mathrm{g}$, and $8.46 \%)$. Moreover, symbiotic had the best lipid profile, random blood sugar, liver functions, antioxidant parameters and immune response and had the highest number of beneficial bacteria (Lactobacillus) and the lowest number of harmful bacteria (E coli and Salmonella) compared to control. It can be recommended that symbiotic, prebiotic and probiotic can be used as safe, economic and healthy alternatives to avilamycin (antibiotic) as growth promoters.
\end{abstract}

Keywords: probiotics, prebiotics, synbiotics, alternatives, antibiotic growth promoters, quail.

\section{INTRODUCTION}

Long time ago, the use of antibiotics in poultry diets as a growth promoter (AGP) unfortunately led to poultry antibiotic resistance (Shazali et al. 2014). Therefore, the poultry industry met a great challenge to sustain growth performance due to expensive feed costs, the restriction of antimicrobial use in feeds and high residue levels in broiler meat (Olatoye and Ehinwomo, 2010). The poultry consumers, researchers and nutritionists are curious about finding proper alternatives to AGP such as phytobiotics, probiotics, prebiotics and synbiotics as useful and safe feed additives that can augment gut health and productivity.

Probiotic is a live microbial feed additive that beneficially affects through improving the microbial balance in the host animal intestine (Jaiswal et al., 2017). Hamasalim (2015) defined prebiotic as an indigestible fermented diet substrates that selectively stimulate the microflora in gastrointestinal tract (composition, growth and activity). Synbiotic refer to nutritional additive combining probiotic and prebiotic in a form of synergism, hence, synbiotic can enhance their isolated beneficial effects. Lately, several authors reported that probiotic, prebiotic or its combination supplemented to broiler diets significantly improved live body weight, live body weight gain and feed efficiency (Oliva et al., 2016; Alsultan et al., 2016 and Calik et al., 2017) increased immune response and the intestinal microflora compared with antibiotic which decreased it (Mazhari et al., 2016) moreover, the synbiotic addition revealed the best immune response and ileal microbiology. On the other hand, probiotic, prebiotic and synbiotic had a significant decreasing effect on broiler serum cholesterol compared with flavomycin (Ashayerzadeh et al., 2011) and enhancing anti-oxidant enzyme activities (Aluwong et al., 2013) and 


\section{Abdel-Kader et al.}

modified gut microflora by increasing the beneficial bacteria, high immune response which reflected as zero mortalities (Bajagai et al . 2017) and increasing carcass dressing \% and all carcass cuts with no differences in giblets (Musaad et al . 2017).

\section{MATERIALS AND METHODS}

\section{Experimental birds design and diets}

A total of 225, one day-old quail were obtained from market and adapted for 10 days. Quails were randomly distributed at equal body weights into five groups as a control group (with no additives), antibiotic group (control diet + sub-therapeutic dose of avilamycin $8 \mathrm{mg} / \mathrm{kg}$ diet ), prebiotic group (control diet $+800 \mathrm{~g}$ Biolex ${ }^{\circledR} \mathrm{MB} 40 /$ ton$)$, probiotic group (control diet $+400 \mathrm{~g}$ AmPhi-BACT/ton) and synbiotic group (control diet $+800 \mathrm{~g}$ Pre $+400 \mathrm{~g}$ Pro). Each group was replicated three times, 15 chicks /replicate. Chicks were housed in a five decks, three sections quail cages with stand and dropping pans with automatic watering. The control diet was formulated to meet the nutrient requirements of the quails during the experiment period from 0 to 38 days (NRC, 1994). The composition of the basal diet is presented in Table 1. Chicks were exposed to continuous lighting and were fed and watered ad libitum. The birds were vaccinated against Newcastle virus (Lasota) via spraying at 31 day of age.

Table (1). Composition of the experimental diet \%

\begin{tabular}{|c|c|}
\hline Ingredient & $\%$ \\
\hline Maize & 56.0 \\
\hline Soybean meal (44 CP \%) & 32.0 \\
\hline Plant concentrate meal ${ }^{1}(50 \mathrm{CP} \%)$ & 10.3 \\
\hline Vegetable oil & 0.5 \\
\hline DL-methionine & 0.1 \\
\hline $\operatorname{Salt}(\mathrm{NaCl})$ & 0.3 \\
\hline Vitamin and mineral premix ${ }^{2}$ & 0.3 \\
\hline Dicalcuom phosphate & 0.5 \\
\hline \multicolumn{2}{|l|}{ Calculated analysis } \\
\hline Metabolizable energy (kcal/kg) & 2919 \\
\hline Crude protein & 24.0 \\
\hline Crude fiber & 3.5 \\
\hline Calcium & 0.8 \\
\hline Available phosphorus & 0.5 \\
\hline \multicolumn{2}{|c|}{ '-Plant concentrate contains (\%): CP 50, CF 1.3, Ca4.72, Av P 3.1, lysine 2.8, methionine 2.1 and ME $2650 \mathrm{kcal} / \mathrm{kg}$. } \\
\hline
\end{tabular}

\section{Growth parameters measured and carcass traits}

Live body weights of chicks (LBW) were individually weighed and feed consumptions per pen were weekly recorded (FI), the uneaten feed discarded, live body weight gain (BWG), growth rate (GR, according to Brody, 1945), feed conversion ratio (FCR) and performance index (PI, according to North, 1981) were calculated. On day 38 of age, six birds from each group were reweighed and slaughtered by cutting the Jugular vein, defeathered and eviscerated. Carcass yield was calculated from eviscerated weight and the dressing\% was calculated, giblets weight was measured and their percentages were calculated while blood samples were collected for blood analysis. The body chemical composition was determined in triplicate according to the AOAC (1995) procedure.

\section{Blood biochemical, anti-oxidant and immunity}

Individual 42 blood samples were collected in dry clean centrifuge tubes at slaughter and serum was separated by centrifugation at $3000 \mathrm{rpm}$ for 15 minutes and assigned for subsequent determination. Quantitative determination was done for the following: total cholesterol (Chol), high density lipoproteins (HDL), low density lipoproteins (LDL), very low density lipoproteins (VLDL) triglycerides (Tri G), 
Aspartate aminotransferase (AST) and Alanine aminotransferase (ALT). All blood biochemical parameters were calorimetrically determined using commercial diagnosing kits (produced by Spectrum Diagnostics Company, Egypt). The glutathione peroxidase (GPx, EC 1.11.1.9) calorimetrically determined according to Paglia and Valentine (1967) and thiobarbaturic acid- reactive substances' (TBAR) were performed according to Yagi (1998) using commercial diagnosing kits produced by Cayman Chemical Company (USA). The method used for the assay of chicken immunoglobulin's Isotopes $\operatorname{IgG}$, IgM, and $\operatorname{IgA}$ in Sandwich ELISA described by Erhard et al. (1992) the absorbance measured on an ELISA plate reader set at $450 \mathrm{~nm}$.

\section{Microbial analysis}

Straightaway after slaughter, intestinal content was collected in sterile glass containers, digesta was evacuated and mixed. The sealed containers were kept in the laboratory at $4{ }^{\circ} \mathrm{C}$ till enumeration of microbial population. Samples (1g of the mixed fresh mass) were taken into sterile test tubes, diluted 1:10 in sterile $0.1 \%$ peptone solution and homogenized for $3 \mathrm{~min}$ in a Stomacher homogenizer. Ten fold serial dilutions up to $10^{-7}$ of each sample were prepared in nine $\mathrm{ml}$ of $0.1 \%$ sterile peptone solution. Viable counts of Salmonella ssp, Escherichia coli (E. coli) and Lactobacilli ssp were performed. One milliliter of the serial dilution was incubated into sterile Petri dishes and sealed with an appropriate medium. Lactobacillus spp. colony count was determined using MRS agar (Biokar Diagnostic, France) after incubation in an anaerobic chamber at $37{ }^{\circ} \mathrm{C}$ for $72 \mathrm{~h}$. Salmonella and E. coli colonies were counted on brilliant green agar plate and incubated at $37^{\circ} \mathrm{C}$ for $24 \mathrm{~h}$ ). After cultivation in Petri dishes, the total colony count for Lactobacilli, Salmonella and E. coli was then calculated as the number of colonies by reciprocal of the dilution. The microbial counts were determined as colony forming units (cfu) per gram of sample.

\section{Statistical analysis:}

Using General Linear Models (GLM) procedure of SPSS (2013), studied traits were subjected to a two-way analysis of variance with treatment and sex as main effects as follows:

$$
\mathrm{Y}_{\mathrm{ijk}}=\mu+\mathrm{Ti}+\mathrm{Sj}+\mathrm{e}_{\mathrm{ijk}} \text {. }
$$

Where: $\mathrm{Y}_{\mathrm{ijk}}$ : Observed value in the $\mathrm{i}^{\text {th }}$ treatment of the $\mathrm{j}^{\text {th }}$ sex of the kth individual, $\mu$ : Overall mean, Ti: Treatment effect (i: 1 to 7), $S_{\mathrm{j}}$ : Sex effect (j: 1 and 2) and $\mathrm{e}_{\mathrm{ijk}}$ : Random error term. Means were compared for main effects by Duncan's new multiple range test (Duncan's, 1955) when significant F values were obtained.

\section{RESULTS AND DISCUSSION}

\section{Growth and carcass traits}

Treatment effect resulted in significant $(\mathrm{P} \leq 0.001)$ differences in growth traits studied at $38 \mathrm{~d}$ and 10 to 38 days of age. The groups fed diets supplemented with Synbiotic, Probiotic and Prebiotic in a

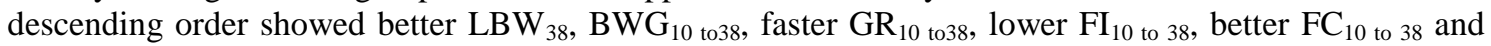
higher $\mathrm{PI}_{10}$ to 38 as compared with the groups fed supplemented with avilamycin and the control diets. Similar significant effects due to sex were found in $\mathrm{LBW}_{38}, \mathrm{BWG}_{10 \text { to38 }}$, better $\mathrm{FC}_{10}$ to 38 and higher $\mathrm{PI}_{10}$ to 38 which were in favor of females (Table 2). Supplementing poultry diets with antibiotics as growth promoters increased microbial population's resistance which may threatens consumer health. Therefore, there has been a critical need to find an antibiotic alternative such as probiotics, prebiotics, and synbiotics. These alternative additives could be associated with a more efficient nutrient utilization (i.e. energy, protein, minerals and vitamins) from feed, which in turn results increasing feed efficiency by improving intestinal microflora population, intestinal integrity and stimulating appetite as well as stimulating the immune system (Al-Sultan et al., 2016) which agreed with the current results.

Dietary prebiotics, probiotic, synbiotic changed intestinal microflora towards beneficial bacteria which play an important role in the prevention of colonization by pathogens in the gastrointestinal tract of chickens through competitive exclusion (Lan et al., 2005) and to maintain healthy gut which is a key to the best growth performance (Tufan and Bolacali 2017) and healthy bird through changing small intestine morphological, by increasing villus height, villus width, and VH: CD ratio (Al-Sultan et al., 2016). Bacillus species are known to produce several extracellular enzymes including $\alpha$-amylases and cellulose, which increase nutrient digestibility and absorption. Moreover, they stimulate growth and proliferation of beneficial facultative anaerobic bacteria, such as Lactobacilli, by creating an anaerobic environment within the gut, which can decrease pathogenic bacteria colonization and improve intestinal 
integrity (Calik et al. 2017). Regarding sex, females showed better performance than males in BW, BWG and FCR in the growth period, except total FC and total FI (Tufan and Bolacali 2017) which partly agreed with the present study.

Table (2). Effects of treatment and sex on growth traits of Japanese quail (Main effects)

\begin{tabular}{|c|c|c|c|c|c|c|c|}
\hline Item & $\begin{array}{c}\mathrm{LBW}_{10 \mathrm{~d}} \\
(\mathrm{~g})\end{array}$ & $\begin{array}{c}\mathrm{LBW}_{38 \mathrm{~d}} \\
(\mathrm{~g})\end{array}$ & $\begin{array}{c}\mathrm{BWG}_{10-38} \\
(\mathrm{~g})\end{array}$ & $\begin{array}{c}\text { FI }_{10-38} \\
(\mathrm{~g})\end{array}$ & $\begin{array}{c}\mathrm{FC}_{10-38} \\
(\mathrm{~g} / \mathrm{g})\end{array}$ & $\begin{array}{c}\mathrm{GR}_{10-38} \\
\mathrm{~g} / \mathrm{g}\end{array}$ & $\begin{array}{c}\mathrm{PI}_{10-38} \\
(\%)\end{array}$ \\
\hline \multicolumn{8}{|c|}{ Treatment effect: } \\
\hline Control & 40.68 & $201.9^{\mathrm{d}}$ & $160.41^{\mathrm{d}}$ & $584.22^{\mathrm{a}}$ & $3.67^{\mathrm{a}}$ & $1.33^{c}$ & $5.56^{\mathrm{d}}$ \\
\hline Avilamycin & 41.50 & $219.68^{c}$ & $178.19^{c}$ & $583.64^{\mathrm{a}}$ & $3.29^{b}$ & $1.37^{\mathrm{b}}$ & $6.73^{c}$ \\
\hline Prebiotic & 41.92 & $226.99^{b}$ & $185.08^{b}$ & $536.26^{\mathrm{b}}$ & $2.91^{\mathrm{c}}$ & $1.38^{\mathrm{ab}}$ & $7.90^{\mathrm{b}}$ \\
\hline Probiotic & 41.71 & $228.83^{a b}$ & $187.12^{b}$ & $539.24^{\mathrm{b}}$ & $2.90^{\mathrm{c}}$ & $1.38^{\mathrm{ab}}$ & $8.03^{\mathrm{b}}$ \\
\hline Synbiotic & 41.44 & $234.41^{\mathrm{a}}$ & $192.97^{\mathrm{a}}$ & $538.90^{\mathrm{b}}$ & $2.81^{\mathrm{c}}$ & $1.40^{\mathrm{a}}$ & $8.46^{\mathrm{a}}$ \\
\hline SE & 0.85 & 2.25 & 1.88 & 4.70 & 0.4 & 0.01 & 0.16 \\
\hline Probability (P) & NS & $\mathrm{P} \leq 0.001$ & $\mathrm{P} \leq 0.001$ & $\mathrm{P} \leq 0.001$ & $\mathrm{P} \leq 0.001$ & $\mathrm{P} \leq 0.001$ & $\mathrm{P} \leq 0.001$ \\
\hline \multicolumn{8}{|l|}{ Sex effect: } \\
\hline Females $(\mathrm{F})$ & 42.35 & $227.82^{\mathrm{a}}$ & $185.47^{\mathrm{a}}$ & 554.65 & $3.03^{b}$ & 1.37 & $7.76^{\mathrm{a}}$ \\
\hline Males (M) & 40.55 & $216.58^{b}$ & $176.03^{b}$ & 558.25 & $3.20^{\mathrm{a}}$ & 1.37 & $6.91^{b}$ \\
\hline SE & 0.54 & 1.42 & 1.20 & 2.92 & 0.03 & 0.01 & 0.10 \\
\hline Probability (P) & NS & $\mathrm{P} \leq 0.001$ & $\mathrm{P} \leq 0.001$ & NS & $\mathrm{P} \leq 0.001$ & NS & $\mathrm{P} \leq 0.001$ \\
\hline F-M & +1.8 & +11.24 & +9.44 & -3.60 & -0.17 & 0.00 & +0.85 \\
\hline
\end{tabular}

Significant differences $(\mathrm{P} \leq 0.05)$ were shown only for dressed meat and meat $\%$ favoring the group fed the diet supplemented with avilamycin and the probiotic followed by prebiotic and symbiotic classified in a descending order had lower estimates for these traits however, insignificant treatment effects were observed for other carcass traits either absolute or \%. Males had higher dressing\% $(\mathrm{P} \leq 0.05)$, meat \% (P $\leq 0.01)$ and lower giblet weight $(\mathrm{P} \leq 0.01)$ than females (Table 3 ). However, adding synbiotic, probiotic and prebiotic had no effect on other internal organs and carcass parameters is consistent with other studies (Sarangi et al., 2016) which agreed with the present study. The result of the present study that carcass yield was higher in male than in females, whereas female had higher giblets than males, was consistent with those of Tufan and Bolacali (2017)

Table (3). Carcass traits of growing quails at slaughter as affected by treatment and sex (Main effects).

\begin{tabular}{|c|c|c|c|c|c|c|}
\hline Item & Edible parts $(\mathrm{g})$ & $\begin{array}{c}\text { Dressing } \\
(\%)\end{array}$ & $\begin{array}{l}\text { Dressed } \\
\text { meat }(\mathrm{g})\end{array}$ & $\begin{array}{c}\text { Meat } \\
(\%)\end{array}$ & $\begin{array}{l}\text { Giblets } \\
\text { (g) }\end{array}$ & $\begin{array}{c}\text { Giblets } \\
(\%)\end{array}$ \\
\hline \multicolumn{7}{|l|}{ Treatment effect: } \\
\hline Control & 155.89 & 75.45 & $79.65^{a b}$ & $38.54^{\mathrm{ab}}$ & 12.74 & 6.20 \\
\hline Avilamycin & 176.88 & 76.70 & $94.82^{\mathrm{a}}$ & $40.99^{\mathrm{a}}$ & 14.18 & 6.11 \\
\hline Prebiotic & 165.91 & 78.52 & $73.67^{b}$ & $34.92^{\mathrm{b}}$ & 14.36 & 5.81 \\
\hline Probiotic & 171.78 & 76.00 & $81.50^{\mathrm{ab}}$ & $36.16^{\mathrm{b}}$ & 13.18 & 6.67 \\
\hline Synbiotic & 154.46 & 74.93 & $70.73^{b}$ & $33.92^{\mathrm{b}}$ & 13.13 & 6.41 \\
\hline SE & 7.33 & 1.94 & 4.97 & 1.49 & 1.03 & 0.39 \\
\hline Probability (P) & NS & NS & $\mathrm{P} \leq 0.05$ & $\mathrm{P} \leq 0.05$ & NS & NS \\
\hline \multicolumn{7}{|l|}{ Sex effect: } \\
\hline Females $(\mathrm{F})$ & 167.93 & $73.90^{\mathrm{b}}$ & 79.89 & $34.96^{\mathrm{b}}$ & $14.85^{\mathrm{a}}$ & 6.52 \\
\hline Males (M) & 161.99 & $78.73^{\mathrm{a}}$ & 80.14 & $38.85^{\mathrm{a}}$ & $12.18^{\mathrm{b}}$ & 5.96 \\
\hline SE & 4.63 & 1.23 & 3.15 & 0.94 & 0.65 & 0.25 \\
\hline Probability (P) & NS & $\mathrm{P} \leq 0.05$ & NS & $\mathrm{P} \leq 0.01$ & $\mathrm{P} \leq 0.01$ & NS \\
\hline $\mathrm{F}-\mathrm{M}$ & 5.94 & -4.83 & -0.25 & -3.89 & 2.67 & 0.56 \\
\hline
\end{tabular}


There were significant $(\mathrm{P} \leq 0.05)$ treatment effects on carcass ash\% and NFE\%, carcasses for the group fed the diet supplemented with symbiotic was higher than other treatments whereas those fed the diet supplemented with probiotic had higher NFE\%. Males had significantly higher ash\% than females, however sex did not influence other carcass chemical components (Table 4).

Table (4). Carcass chemical composition of growing quails affected by treatment and sex (Main effects).

\begin{tabular}{|c|c|c|c|c|c|}
\hline Item & Moisture\% & $\mathrm{CP} \%$ & Fat $\%$ & Ash\% & NFE\% \\
\hline \multicolumn{6}{|l|}{ Treatment effect: } \\
\hline Control & 66.60 & 20.60 & 9.41 & $2.00^{\mathrm{b}}$ & $1.38^{\mathrm{a}}$ \\
\hline Avilamycin & 66.93 & 20.34 & 9.42 & $1.99^{\mathrm{b}}$ & $1.32^{\mathrm{ab}}$ \\
\hline Prebiotic & 66.75 & 20.69 & 9.23 & $2.05^{\mathrm{ab}}$ & $1.28^{\mathrm{ab}}$ \\
\hline Probiotic & 66.29 & 20.82 & 9.67 & $1.84^{\mathrm{b}}$ & $1.38^{\mathrm{a}}$ \\
\hline Synbiotic & 65.77 & 21.11 & 9.63 & $2.26^{\mathrm{a}}$ & $1.22^{\mathrm{b}}$ \\
\hline $\mathrm{SE}$ & 0.29 & 0.21 & 0.17 & 0.08 & $? ? ?$ \\
\hline Probability (P) & NS & NS & NS & $\mathrm{P} \leq 0.05$ & $\mathrm{P} \leq 0.05$ \\
\hline \multicolumn{6}{|l|}{ Sex effect: } \\
\hline Females (F) & 66.62 & 20.65 & 9.49 & $1.94^{\mathrm{b}}$ & 1.30 \\
\hline Males (M) & 66.31 & 20.77 & 9.46 & $2.12^{\mathrm{a}}$ & 1.33 \\
\hline SE & 0.19 & 0.13 & 0.11 & 0.05 & 0.03 \\
\hline Probability (P) & NS & NS & NS & $\mathrm{P} \leq 0.05$ & NS \\
\hline $\mathrm{F}-\mathrm{M}$ & 0.31 & -0.12 & 0.03 & -0.18 & -0.03 \\
\hline
\end{tabular}

SE: Standard error NS: Not significant

a...: Means within the same column with different superscript

\section{Blood constituents}

All serum biochemical indices at slaughter were (lipid profile and RBS) significantly affected by treatment effect, except liver enzymes (AST and ALT). Supplementing diets with symbiotic, probiotic and prebiotic (in a descending order) resulted in desirably decreased total Chol, LDL, VLDL, RBS and preferably increased HDL compared with the supplemented diet with avilamycin and control groups.

Table (5). Serum biochemical indices at slaughter as affected by treatment and sex (Main effects).

\begin{tabular}{|c|c|c|c|c|c|c|c|c|}
\hline Item & $\begin{array}{c}\text { Total Chol } \\
(\mathrm{mg} / \mathrm{dl})\end{array}$ & $\begin{array}{c}\text { HDL } \\
(\mathrm{mg} / \mathrm{dl})\end{array}$ & $\begin{array}{c}\text { LDL } \\
(\mathrm{mg} / \mathrm{dl})\end{array}$ & $\begin{array}{l}\text { VLDL } \\
(\mathrm{mg} / \mathrm{dl})\end{array}$ & $\begin{array}{c}\text { RBS } \\
(\mathrm{mg} / \mathrm{dl})\end{array}$ & $\begin{array}{c}\text { Tri G } \\
(\mathrm{mg} / \mathrm{dl})\end{array}$ & $\begin{array}{l}\text { AST } \\
(\mathrm{U} / \mathrm{L})\end{array}$ & $\begin{array}{l}\text { ALT } \\
(\mathrm{U} / \mathrm{L})\end{array}$ \\
\hline \multicolumn{9}{|c|}{ Treatment effect: } \\
\hline Control & $189.64^{\mathrm{a}}$ & $104.13^{\mathrm{b}}$ & $67.51^{\mathrm{a}}$ & $18.01^{\mathrm{b}}$ & $235.68^{\mathrm{a}}$ & $124.79^{\mathrm{a}}$ & 99.12 & 17.33 \\
\hline Avilamycin & $188.32^{\mathrm{a}}$ & $99.96^{\mathrm{b}}$ & $64.15^{\mathrm{a}}$ & $24.22^{\mathrm{a}}$ & $233.53^{\mathrm{a}}$ & $120.99^{\mathrm{ab}}$ & 98.90 & 21.83 \\
\hline Prebiotic & $165.79^{b}$ & $103.15^{\mathrm{b}}$ & $47.48^{\mathrm{b}}$ & $15.17^{\mathrm{b}}$ & $213.39^{b}$ & $120.70^{\mathrm{ab}}$ & 97.83 & 23.42 \\
\hline Probiotic & $165.22^{\mathrm{b}}$ & $111.50^{\mathrm{a}}$ & $38.45^{\mathrm{c}}$ & $15.27^{\mathrm{b}}$ & $213.83^{b}$ & $120.62^{\mathrm{ab}}$ & 95.37 & 20.78 \\
\hline Synbiotic & $157.12^{\mathrm{c}}$ & $111.63^{\mathrm{a}}$ & $33.58^{\mathrm{c}}$ & $11.90^{\mathrm{b}}$ & $207.65^{\mathrm{b}}$ & $111.83^{\mathrm{b}}$ & 93.45 & 21.08 \\
\hline SE & 2.47 & 1.92 & 2.56 & 1.98 & 2.84 & 3.12 & 1.64 & 1.88 \\
\hline Probability & $\mathrm{P} \leq 0.001$ & $\mathrm{P} \leq 0.001$ & $\mathrm{P} \leq 0.001$ & $\mathrm{P} \leq 0.01$ & $\mathrm{P} \leq 0.001$ & $\mathrm{P} \leq 0.05$ & NS & NS \\
\hline \multicolumn{9}{|l|}{ Sex effect: } \\
\hline Females (F) & 178.17 & 108.39 & 52.83 & 16.95 & 217.01 & 121.82 & 96.01 & 20.59 \\
\hline Males (M) & 168.27 & 103.75 & 47.64 & 16.88 & 224.62 & 117.75 & 97.85 & 21.19 \\
\hline SE & 1.56 & 1.21 & 1.62 & 1.25 & 1.79 & 1.97 & 1.04 & 1.19 \\
\hline Probability & $\mathrm{P} \leq 0.001$ & $\mathrm{P} \leq 0.05$ & $\mathrm{P} \leq 0.05$ & NS & $\mathrm{P} \leq 0.01$ & NS & NS & NS \\
\hline $\mathrm{F}-\mathrm{M}$ & +9.90 & +4.64 & +5.19 & +0.07 & -7.61 & +4.07 & -1.84 & -0.60 \\
\hline
\end{tabular}




\section{Abdel-Kader et al.}

Females had higher total Chol ( $\mathrm{P} \leq 0.001)$, HDL and LDL $(\mathrm{P} \leq 0.05)$ but lower RBS than males (Table 5). Probiotic supplementation significantly reduces the serum Chol level of the chickens (Ashayerzadeh et al., 2011). Synthesis of bile acids from Chol in the liver is the most important way of Chol excretion (Wilson et al., 1998). The use of probiotics and prebiotics can decomposing bile salts and deconjugate production of enzymes by the activity of lactic acid bacteria, as well as reduction of the $\mathrm{pH}$ in the intestinal tract can be effective in reducing the Chol concentration. Solvability of non-conjugate bile acids is lowered at a low $\mathrm{pH}$ and consequently, they are absorbed less from the intestine and are excreted more in the feaces (Klaver and Van der Meer, 1993). Consequently, the liver, for re-establishment of the hepatic cycle of bile acids, coverts more Chol concentration into the tissues and therefore their concentrations in the blood is reduced (Ros, 2000). In the growing birds, VLDL is the most important triglycerides carrier. A reduction in the serum triglycerides level may be due to an increase in the population of lactic acid bacteria in the gastrointestinal tract. Santose et al . (1995) suggested that this bacterium can be effective in reducing the activity of acetyl coenzyme A carboxylase (the enzyme limiting the synthesis rate of fatty acids).

\section{Blood antioxidants and Immune globulins}

Either antioxidant parameters or immune responses were affected $(\mathrm{P} \leq 0.001)$ by treatment effect. Quail fed the diet supplemented with symbiotic followed by prebiotic and probiotic had suitably the highest GPx, IgG, IgA, IgM and the lowest TBAR as compared to other groups. Anti-oxidant enzymes are most effective when acting synergistically with one another or with other components of the antioxidant barrier of the organism when their activity remains balanced. It has been shown that nutrition plays a vital role in maintaining the pro-oxidant-antioxidant balance (Cowey, 1986).

Females had lower TBAR than males $(\mathrm{P} \leq 0.05)$ whereas sex did not affect GPx and all immune responses (Table 6). Immune system enhancement by antibiotic alternatives is attributed to the increase in macrophage activity and higher antibody production on the mucosal surface of some tissues such as the intestine wall. Dhama and Singh (2010)revealed that regular use of probiotics has a prominent effect on the immune system viz. stimulation of both humeral and cell mediated immunity through enriched production of natural interferons/cytokines, increased macrophage, lymphocyte and natural killer cell activity, up regulated oxidative burst in heterophils, and increased immunoglobulin (i.e. $\operatorname{IgG}, \operatorname{IgM}$ and $\operatorname{IgA}$ ). Probiotics produce a gut-stabilising effect; and immune regulation, particularly through balanced control of pro-inflammatory and anti-inflammatory cytokines.

\section{Intestinal microflora}

Diets supplemented with prebiotic, symbiotic and probiotic significantly increased useful bacteria (Lactobacillus, $\mathrm{P} \leq 0.001)$ as compared to the avilamycin group and decreased $\mathrm{E}$ coli $(\mathrm{P} \leq 0.001)$ than the control group whereas the avilamycin group had the lowest E coli and Salmonella counts. Insignificant sex effects were obtained on useful and harmful intestinal bacteria in growing quails (Table 7). In the present study, antibiotic decreased ileal microbial population of Lactobacillus bacteria while the other growth promoters increased it $(\mathrm{P} \leq 0.001)$. Probiotics as antibiotic alternative can inhibit the growth of pathogenic bacteria and improve the population of non-pathogenic bacteria like Lactobacillus by decreasing $\mathrm{pH}$ of the gastrointestinal tract (Mazhari et al., 2016) and produce substances such as lactoferrin, lysozyme, as well as several organic acids and volatile fatty acids lowering the pH below that essential for the survival and inhibit the growth of pathogenic, such as E.coli and Salmonella spp. (Fuller 1989).

\section{CONCLUSION}

Groups fed diets supplemented with synbiotic, probiotic and prebiotic in a descending order showed better growth performance than the groups fed diet supplemented with avilamycin and the control. Supplementing diets with synbiotic, probiotic and prebiotic (in a descending order) resulted in desirably decreased total Chol, LDL, VLDL, RBS and preferably increased HDL, had suitably the highest GPx, $\mathrm{IgG}, \operatorname{IgA}, \operatorname{IgM}$ and the lowest TBAR as compared to other groups, and significantly increased useful bacteria (Lactobacillus, $\mathrm{P} \leq 0.001)$ and decreased $\mathrm{E}$ coli $(\mathrm{P} \leq 0.001)$ than the control group whereas the avilamycin group had the lowest E coli and Salmonella counts. Therefore, it can be concluded that symbiotic, prebiotic and probiotic in a descending order can be used as safe, economic and healthy alternatives to avilamycin (antibiotic) as growth promoters. 
Table (6). Antioxidant parameters and immune response as affected by different dietary treatments and sex (Main effects).

\begin{tabular}{|c|c|c|c|c|c|}
\hline Item & \multicolumn{2}{|c|}{ Antioxidant parameters } & \multicolumn{3}{|c|}{ Immune response } \\
\hline \multicolumn{6}{|c|}{ Treatment effect: } \\
\hline & $\begin{array}{c}\text { GPx } \\
(\mathrm{nmol} / \mathrm{min} / \mathrm{ml})\end{array}$ & $\begin{array}{c}\text { TBAR } \\
(\mathrm{nmol} / \mathrm{ml})\end{array}$ & $\begin{array}{c}\mathrm{IgG} \\
(\mathrm{mg} / \mathrm{dl})\end{array}$ & $\begin{array}{c}\mathrm{IgA} \\
(\mathrm{mg} / \mathrm{dl})\end{array}$ & $\begin{array}{c}\text { IgM } \\
(\mathrm{mg} / \mathrm{dl})\end{array}$ \\
\hline Control & $6.43^{\mathrm{c}}$ & $1.86^{\mathrm{a}}$ & $936.15^{c}$ & $175.53^{c}$ & $93.62^{c}$ \\
\hline Avilamycin & $6.75^{\mathrm{c}}$ & $1.76^{\mathrm{a}}$ & $848.80^{\mathrm{d}}$ & $159.15^{\mathrm{d}}$ & $84.88^{\mathrm{d}}$ \\
\hline Prebiotic & $7.55^{\mathrm{b}}$ & $1.43^{\mathrm{b}}$ & $1015.23^{\mathrm{ab}}$ & $190.36^{\mathrm{ab}}$ & $101.52^{\mathrm{ab}}$ \\
\hline Probiotic & $7.37^{\mathrm{b}}$ & $1.56^{\mathrm{b}}$ & $967.35^{\mathrm{bc}}$ & $181.38^{b c}$ & $96.74^{\mathrm{bc}}$ \\
\hline Synbiotic & $8.33^{\mathrm{a}}$ & $1.12^{\mathrm{c}}$ & $1045.50^{\mathrm{a}}$ & $196.03^{\mathrm{a}}$ & $104.55^{\mathrm{a}}$ \\
\hline $\mathrm{SE}$ & 0.21 & 0.05 & 17.19 & 3.22 & 1.72 \\
\hline Probability $(\mathrm{P})$ & $\mathrm{P} \leq 0.001$ & $\mathrm{P} \leq 0.001$ & $\mathrm{P} \leq 0.001$ & $\mathrm{P} \leq 0.001$ & $\mathrm{P} \leq 0.001$ \\
\hline \multicolumn{6}{|l|}{ Sex effect: } \\
\hline Females $(\mathrm{F})$ & 7.39 & $1.48^{\mathrm{b}}$ & 947.29 & 177.62 & 94.73 \\
\hline Males (M) & 7.19 & $1.61^{\mathrm{a}}$ & 977.93 & 183.36 & 97.79 \\
\hline SE & 0.13 & 0.03 & 11.26 & 2.11 & 1.13 \\
\hline Probability $(\mathrm{P})$ & NS & $\mathrm{P} \leq 0.05$ & NS & NS & NS \\
\hline F- M & 0.20 & -0.13 & -30.64 & -5.74 & -3.06 \\
\hline
\end{tabular}

Table (7). Useful and harmful intestinal bacteria in growing quails as affected by different dietary treatments and sex (Main effects).

\begin{tabular}{|c|c|c|c|}
\hline Item & $\begin{array}{l}\text { Lactobacillus } \\
\text { (log } 10 \text { cfug) }\end{array}$ & $\begin{array}{c}\text { E coli } \\
(\log 10 \mathrm{cfug})\end{array}$ & $\begin{array}{l}\text { Salmonella } \\
(\log 10 \text { cfug) }\end{array}$ \\
\hline \multicolumn{4}{|l|}{ Treatment effect: } \\
\hline Control & $6.52^{a}$ & $8.40^{\mathrm{a}}$ & $8.22^{a}$ \\
\hline Avilamycin & $4.72^{\mathrm{b}}$ & $5.19^{\mathrm{d}}$ & $5.03^{\mathrm{b}}$ \\
\hline Prebiotic & $7.18^{\mathrm{a}}$ & $7.98^{\mathrm{ab}}$ & $7.77^{\mathrm{a}}$ \\
\hline Probiotic & $7.02^{\mathrm{a}}$ & $7.73^{\mathrm{bc}}$ & $7.77^{\mathrm{a}}$ \\
\hline Synbiotic & $7.15^{\mathrm{a}}$ & $7.38^{\mathrm{c}}$ & $7.63^{\mathrm{a}}$ \\
\hline SE & 0.26 & 0.18 & 0.19 \\
\hline Probability (P) & $\mathrm{P} \leq 0.001$ & $\mathrm{P} \leq 0.001$ & $\mathrm{P} \leq 0.001$ \\
\hline \multicolumn{4}{|l|}{ Sex effect: } \\
\hline Females (F) & 6.48 & 7.35 & 7.23 \\
\hline Males (M) & 6.56 & 7.32 & 7.34 \\
\hline $\mathrm{SE}$ & 0.16 & 0.12 & 0.12 \\
\hline Probability (P) & NS & NS & NS \\
\hline F- M & -0.08 & 0.03 & -0.11 \\
\hline
\end{tabular}

\section{REFERENCES}

Al-Sultan, S. I., S.M. Abdel-Raheem, W.R. El-Ghareeb and M.H. A. Mohamed (2016) . Comparative effects of using prebiotic, probiotic, synbiotic and acidifier on growth performance, intestinal microbiology and histomorphology of broiler chicks. Japanese Journal of Veterinary Research 64(Supplement 2): S187-195, 2016.

Aluwong, T., M. Kawu, M. Raji, T. Dzenda, F. Govwang, V. Sinkalu and J. Ayo (2013). Effect of yeast probiotic on growth, antioxidant enzyme activities and malondialdehyde concentration of broiler chickens. Antioxidants, 2 (4), 326-339.

AOAC (1995). Official methods of analysis 16th Ed. Association of official analytical chemists. Washington DC, USA. 
Ashayerzadeh, A., N. Dabir, K. Mirzadeh and M. R. Ghorbani (2011).Effect of dietary supplementation of probiotic and prebiotic on growth indices and serum biochemical parameters of broiler chickens J.Cell Anim. Biol .5; 152-156.

Bajagai , Y.S., D. Zhang, X. LI , P.J. Dart, A.V. Klieve, P. Hugenholtz and W.L. Bryden (2017). Effects of Probiotic Bacillus Amyloliquefaciens $\mathrm{H} 57$ on Performance and Intestinal Microbiota of Chickens.Aust.Poult. Sci. Symp. 2017.....28.

Brody, S. (1945).Bioenergetics and Growth. New York: Reinhold Publishing Co.

Calik, A., B. Ekim, A.G. Bayraktaroğlu, A. Ergün and P. Saçakli (2017). Effects of dietary probiotic and synbiotic supplementation on broiler growth performance and intestinal histomorphology . Ankara Üniv Vet FakDerg, 64, 183-189, 2017.

Cowey, C.B.(1986). The role of nutritional factors in the prevention of peroxidative damage to tissues. Fish Physiol. Biochem. 1986, 2, 171-178.

Dhama, K. and S.D. Singh (2010). Probiotics improving poultry health and production: an overview. Poultry Punch, 26(3): 41.

Duncan, D. B. (1955). The multiple ranges and multiple F Test. Biometrics.11: 1-42.

Erhard, M.H., I. Von Quistorp, I. Schranner, A. Jüngling, B. Kaspers, P. Schmidt and R. Kühlmann (1992). Development of Specific Enzyme-Linked Immunosorbent Antibody Assay Systems for the Detection of Chicken Immunoglobulins G, M, and A Using Monoclonal Antibodies. Poultry Science, Volume 71, Issue 2, 1 February 1992, Pages 302-310.

Fuller, R. (1989). Probiotics in man and animals. J. Appl. Bacterial. 66: 365 - 378.

Hamasalim , H.J. (2015). Oligosaccharides as Prebiotic. Health Journal, 1, 4-9.

Jaiswal, S.K., A.K. Chaturvedani, M. Raza, L. Dilliwar, K. Dhruw and Sahu. Veeren dra (2017). Natural Growth Promoters, Alternative to Antibiotic Growth Promoters on Poultry: Review. International Journal of Science and Technology, Vol. 6, No 1, 2017, 254 - 259. Environment ISSN 2278-3687.

Klaver, F.A.M., and R. Van Der Meer (1993). The assumed assimilation of cholesterol by lactobacilli and Bifidobacteriumbifidum is due to their bile salt-deconjugating activity. Appl. Environ. Microbiol., 59: 1120- 1124.

Lan, Y., M.W. A.Verstegen, S. Tamminga and B. A. Williams (2005). The role of the commensal gut microbial community in broiler chickens. World's Poul. Sci. J., 61: 95-104.

Mazhari , M., O. Esmaeilipour, R. Mirmahmoudi and Y. Badakhshan (2016). Comparison of Antibiotic, Probiotic and Great Plantain (Plantago major L.) on Growth Performance, Serum Metabolites, Immune Response and Ileal Microbial Population of Broilers. Poultry Science Journal 2016, 4(2): 97 105 .

Musaad, I.E., A. M. Kamal and M.A. Mukhtar (2017). Response of Broiler Chicks to Commercial Dietary Microbial Probiotic (Dexflor-Pr) as Natural Growth Promoter Alternative to Antibiotics. World Journal of Pharmacy and Pharmaceutical Sciences Vol 6, Issue 5, 2017.

North, M.O. (1981).Commercial Chicken Production Manual, 2nd Edition. AVI Publishing Company Inc, USA.

NRC (1994) Nutrient Requirements of Domestic Animals. Nutrient requirements of Poultry. $9^{\text {th }}$ Rev. ed. Washington, D.C., USA: National Academy Press.

Olatoye, I.O. and A.A. Ehinwomo (2010). Oxytetracycline residues in edible tissues of cattle slaughtered in Akure, Nigeria. Nigerian Veterinary Journal 31(2), 93-102.

Oliva, D., S.S. Patil, H.H. Savsani, R.J. Padodara, D.D. Garg, S. Marandi and N. Barad (2016). Effect of Dietary Prebiotics, Probiotics and Synbiotics as Feed Additives on Blood Profile and Broiler Performance. International Journal of Science, and Technology, Vol. 5, No 5, 2016, 3546 - 3552 Environments ISSN 2278-3687 (O).

Paglia, D.E. and W.N. Valentine (1967). Studies on the quantitative and qualitative characterization of erythrocyte glutathione peroxidase. J Lab Clin Med. 70:158-169.

Ros, E. (2000). Intestinal absorption of triglyceride and cholesterol. Dietary and pharmacological inhibition to reduce cardiovascular risk. Atherosclerosis., 51: 357-379. 
Santose, U., K. Tanaka, and S. Othani (1995). Effect of dried Bacillus subtilis culture on growth, body composition and hepatic lipogenic enzyme activity in female broiler chicks. Br. J. Nutr., 74: 523-529.

Sarangi, N.R., L.K. Babu, A. Kumar, C. R. Pradhan, P. K. Pati and J. P. Mishra (2016). Effect of dietary supplementation of prebiotic, probiotic, and synbiotic on growth performance and carcass characteristics of broiler chickens. Veterinary World, 9(3): 313-319.

Shazali , N., H.L. Foo, T.C. Loh, D.W. Choe and R.A. Rahim ( 2014). Prevalence of antibiotic resistance in lactic acid bacteria isolated from the faeces of broiler chicken in Malaysia. Gut Pathog. 6:1-7. doi:10.1186/1757-4749-6-1

SPSS (2013). IBM SPSS Statistics for Windows, Version 22.0. Armonk, NY: IBM Corp. Released 2013.

Tufan, T. and M. Bolacali (2017). Effects of dietary addition of synbiotic on the performance, carcass traits, and serum parameters of Japanese quails. Brazilian Journal of Animal Science, vol.46 no.10 Viçosa Oct. 2017.

Wilson, T. A., R. J. Nicolosi, E. J. Rogers, R. Sacchiero and D. J. Goldberg (1998). Studies of cholesterol and bile acid metabolism, and early atherogenesis in hamsters fed GT16-239, a novel bile acid sequestrate (BAS), Atherosclerosis., 40: 315-324.

Yagi, K. (1998). Simple assay for the level of total lipid peroxides in serum or plasma. Methods in Molecular Biology 108, 101-106.

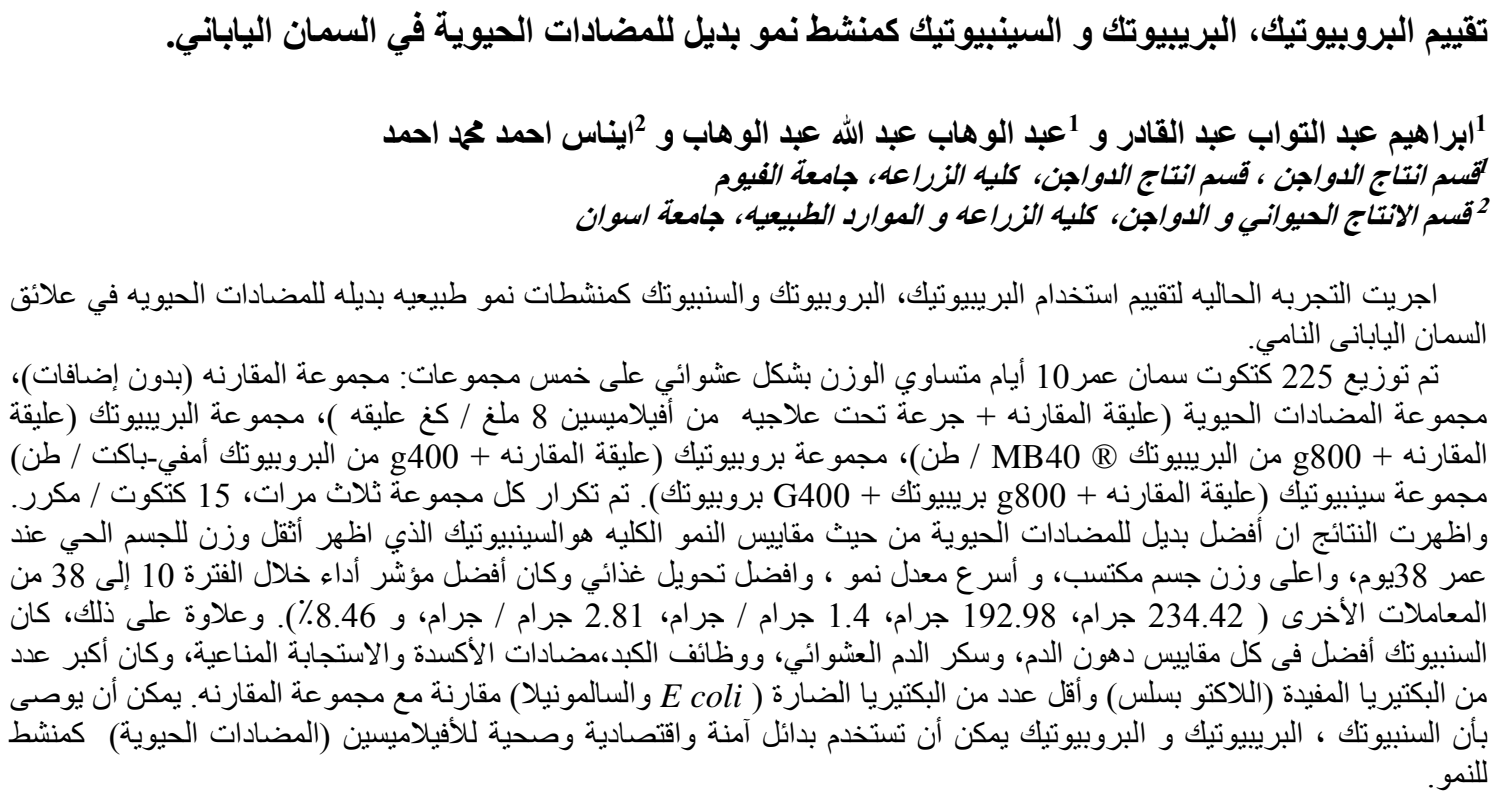

